\title{
The political economy of differentiated integration: The case of common agricultural policy
}

\author{
Thomas Malang ${ }^{1}$ (D) $\cdot$ Katharina Holzinger $^{1}$
}

Published online: 28 May 2020

(C) The Author(s) 2020

\begin{abstract}
The past and arguably the future of the European Union (EU) are characterized by Differentiated Integration (DI). Whereas a number of studies examine country variance in the realization of DI due to state-level characteristics, scholars have rarely addressed sector-specific differentiation. We select Common Agricultural Policy (CAP) for such an analysis - the policy domain with the largest budget, most contestation in the Council of Ministers, most redistribution, and most differentiated legal acts. Building on liberal intergovernmentalism, we develop a demand and supply model to explain the number of opt-outs a country realizes in CAP legislation. We hypothesize that the member states' demand for differentiation is driven by agricultural lobbyism and by the political receptiveness of governments; the supply-side is driven by member states' voting or bargaining power; and the realized differentiations are a consequence of the interaction of demand and supply. Using all differentiations in new CAP legal acts from 1993 to 2012, we test these hypotheses in a time-series cross-section design. We find that the domestic level of agricultural protectionism, conservative parties in government and voting power are robust predictors of the realization of differentiation in CAP. Our results support the general claim of liberal intergovernmentalism, that domestic societal and economic interests and political bargaining power shape the course of (differentiated) integration.
\end{abstract}

Keywords Differentiated integration · Political economy · Common Agricultural Policy · Liberal intergovernmentalism $\cdot$ Protectionism $\cdot$ Lobbyism $\cdot$ Voting power

Electronic supplementary material The online version of this article (https://doi.org/10.1007/s11558-02009384-z) contains supplementary material, which is available to authorized users.

Thomas Malang

thomas.malang@uni-konstanz.de

Katharina Holzinger

https://orcid.org/0000-0003-2917-4744

1 Department of Politics and Public Administration, University of Konstanz, 78457 Constance, Germany 


\section{Introduction}

The long political and academic debate about differentiated integration (DI) in the European Union (EU) has reached another peak since the late 1990s: it was sparked off by Eastern enlargement and the related differentiation in primary law (Schimmelfennig and Winzen 2014) and recently reinforced by Brexit, leading to a discussion of "differentiated disintegration" (Schimmelfennig 2018). We define the phenomenon of "differentiation" as a situation where one or more EU member states are permitted to not apply certain legal rules of the European Treaties or EU secondary law. This way the uniform integration process gets differentiated across member states and policy fields. While political suggestions and normative models of flexible integration accompanied the EU discourse already during the 1970s, the academic literature was scattered and focused on case studies, legal accounts and typologies to capture differentiation (cf. Holzinger and Schimmelfennig 2012). Analytical theories to explain DI (e.g. Leuffen et al. 2013; Jensen and Slapin 2012; Holzinger and Tosun 2019) and systematic empirical evidence (e.g. Winzen 2016; Duttle et al. 2017) are a rather recent phenomenon. Most of the literature concentrated on explaining primary law differentiation, whereas secondary law differentiation earned less attention (see, however, Tuytschaever 1999; Duttle 2016). Moreover, statistical approaches focus mostly on the member state and EU level and do not disaggregate according to policy fields. As Winzen (2016) and Duttle et al. (2017) find that differentiation varies considerably across policy domains, we consider it a promising contribution to analyze sectorspecific differentiated integration.

We select the Common Agricultural Policy (CAP) for such a sector-specific approach for three reasons. First, agriculture looms large and very distinct in the life of the EU and it is a most likely case for secondary law differentiation. While hotly disputed from its very beginnings (Moravcsik 1998, chapter 3), the CAP became quickly the major policy field of the European Communities. The EU has strong policy-making responsibilities for agriculture, implying that agriculture was the most integrated of the EU's sectoral policies until the early 2000s (Nugent 2010:161), when it was outrun by the European Monetary Union. Second, despite this level of integration, agriculture is also the policy field with most realized differentiations, which makes it a prime example for DI (Duttle et al. 2017). In fact, the first differentiations in agricultural policy for Germany and France can already be found in 1962. Third, agricultural policy is the policy field with most contestation in decision-making (Conceicao-Heldt 2012), resulting in most "no" and "abstain" votes in the otherwise consensual decision style of the Council (Bailer et al. 2015). This distinct nature of agricultural policy in the EU is amplified by the fact that the CAP still accounts for $40 \%$ of the EU budget (around 59 billion Euro in 2017). ${ }^{1}$ Agriculture is the only sector almost entirely funded from the EU budget, implying that EU spending replaces national spending to a great degree. Nevertheless, we observe a growing heterogeneity of agricultural structures throughout the EU, due to enlargement, natural endowment, internal technological development or the remaining national agricultural policies. Since agricultural production patterns and lobbyism are heterogeneous across member states, the agricultural policy interests of

\footnotetext{
${ }^{1}$ European Commission, Directorate General for Agriculture and Rural Development 2018: https:/ec.europa. eu/agriculture/sites/agriculture/files/statistics/factsheets/pdf/eu_en.pdf (last accessed 31 March 2019).
} 
these states are also, and increasingly, heterogeneous. Especially the enlargement rounds in 2004 and 2007 contributed to this increase. Combined with the financial importance of the CAP, this heterogeneity made it difficult to reach agreement on agricultural policies after the prize support protectionist approach of the European agricultural policy had come under pressure as a consequence of high cost of overproduction and of international trade negotiations during the 1980s. We argue that one form of reaching agreement on the changing EU agricultural policies after 1992 is the permission of opt-outs from EU law in agriculture. DI is a classical way of accommodating member states' preference heterogeneity.

The goal of this paper is to develop a theory-guided analysis of the factors that drive member states' demand for differentiation and their capacity to achieve opt-outs in the CAP. We theorize and test empirically which politico-economic features are associated with the level of realized differentiation in the agricultural sector. We build on the liberal intergovernmentalist integration theory of Moravcsik (1998) to develop hypotheses on the national demand-side of differentiations, theorizing lobbyism in the agricultural sector and the sector's importance for national governments (see also Redeker and Walter 2020). On the EU level, we expect power distribution in the Council of Agricultural Ministers to account for the capacity to supply differentiation. We test this explanatory approach based on all differentiations in new CAP legal acts from 1993 to 2012.

\section{Differentiated integration in the EU: Definition and previous research}

European integration has been accompanied by political and academic debates on DI ever since the Tindemans Report (Tindemans 1976). Concepts such as 'flexible integration', 'variable geometry', 'multi-speed' Europe, or 'Europe á la Carte' have been discussed, all of which have in common that the member states integrate to different degrees with the EU. While terminology and concepts varied greatly over time, in recent years the academic literature seems to agree on the term differentiated integration (Leuffen et al. 2013) and defines it broadly but succinctly as the territorial variation of validity of EU legal rules within and beyond the EU member states. This includes opt-outs of member states from EU primary or secondary law and opt-ins of non-EU countries applying EU law. In this paper we deal with secondary law differentiation (opt-outs).

The first phase of the DI debate was dominated by political proposals on how to develop the EU after the various enlargement rounds. Further, normative models were suggested by economists, such as the FOCJ concept of Frey and Eichenberger (1996). Holzinger and Schimmelfennig (2012) provide a comparative overview of these approaches. Apart from concepts, the practice of DI in law was examined and typologies were put forward. Stubb (1996) classifies along the temporal, territorial and sectoral dimension, whereas Tuytschaever (1999) distinguishes temporal vs permanent, actorspecific vs general, and potential (optional) vs actual (realized) DI. We include temporal and permanent, specific and general, but solely actual DI in our analysis.

Only after 2000, theoretical accounts to explain DI were developed, most of them based on rationalist frameworks. The general story-line attributes differentiation to an 
increase in heterogeneity among the member states triggered by enlargement rounds. Growing heterogeneity of preferences and capabilities tends to create deadlock in treaty and policy negotiations (De Búrca and Scott 2000). DI provides a way out by allowing the member states to cooperate at different levels of integration (e.g. Dyson and Sepos 2010; Holzinger 2011). Notwithstanding the plausibility of these accounts, more rigorous theories have been proposed that take both the demand and supply of DI into consideration. Based on public goods theory and game theoretic approaches some authors focus on centripetal effects of DI and multi-track arrangements (Kölliker 2001; Hvidsten and Hovi 2015), whereas others emphasize the importance of centrifugal effects (Jensen and Slapin 2012). Schneider (2009) addresses forced and discriminatory $^{2}$ DI: in the course of Eastern enlargement, the EU had denied new members the adoption of certain rules. Holzinger and Tosun (2019) use a signalling game to explain the supply of DI by bargaining power and asymmetric information.

Applying the perspective of integration theories Leuffen et al. (2013) develop an encompassing approach based on hypotheses from an intergovernmentalist, a supranationalist and a constructivist angle. They test these explanations with the most prominent cases of DI in primary law. Apart from this approach, and although Moravcsik and Nicolaidis called for elaborating bargaining theory to deal adequately with exclusion and opt-outs (1999: 83), DI has not been treated systematically in liberal intergovernmentalism. In this paper we build on liberal intergovenmentlism, but contextualize by adapting the model to everyday EU policy-making.

The empirical literature has long concentrated on single cases of opt-outs in primary law although increasingly in an analytical and theory-guided fashion (Kölliker 2001; Leuffen et al. 2013). The theories of DI, however, could not be subjected to rigorous empirical tests before the EUDIFF data sets had been created. While the EUDIFF1 dataset contains all differentiations in EU primary law (Schimmelfennig and Winzen 2014), EUDIFF2 contains the differentiations in secondary law since 1957 (Duttle et al. 2017).

The analysis of secondary law differentiation has so far lead to limited insights. In general, differentiation varies considerably by member state and policy domain. Descriptively, Duttle et al. (2017) find that differentiation is a stable feature of EU legislation which remained stationery over time. Visible peaks are mostly related to enlargement rounds, whereby in particular the Northern accession cohort sticks out with the largest numbers of opt-outs granted. Duttle (2016) tests to which degree three European integration theories - intergovernmentalism, supranationalism and social constructivism - can explain differentiated integration. In addition to some influence of enlargement rounds, he mainly finds that extent and variation in economic interdependence, i.e., trade integration, and domestic veto players have significant effects on the level of a country's opt-outs. Duttle finds no support for other hypotheses which might be a consequence of analyzing differentiations at a high level of aggregation, across all policy fields. The drivers of demand for and supply of DI might, however, be much more specific to the policy domain. We therefore suggest analyzing DI in one prominent EU policy field in which DI is a standard feature: the Common Agricultural Policy.

\footnotetext{
${ }^{2}$ Cf. Schimmelfennig 2014; Schimmelfennig and Winzen 2017; discriminatory differentiations are not subject of our analysis since we concentrate on secondary law opt-outs. Discriminatory DI is mostly manifested in primary law.
} 


\section{The CAP, its reforms, and differentiated integration}

\subsection{The common agricultural policy (CAP)}

Today, agriculture is a relatively small sector in the economy of the EU-28, accounting for only $1.6 \%$ of GDP and some $5 \%$ of employment. ${ }^{3}$ Still, it is a major policy field in the EU, partly as a consequence of its original importance: Moravcsik (1998: 89) reports that in 1956 agricultural employment was $41 \%$ in Italy, 25\% in France and 15\% in Germany; and agricultural GDP amounted to 25\% in Italy, 15\% in France and 11\% in Germany. Thus, agriculture was of high political relevance but there were also crossnational differences and intense preferences of the large member states, in particular France and Germany.

Looking at the history, agriculture as part of a future common market was already mentioned 1957 in the Treaty of Rome. The treaty specified the goals of the CAP in article 39: (1) to increase productivity through technical progress and efficient use of production factors; (2) to ensure a fair standard of living for those employed in agriculture; (3) to stabilize agricultural markets; (4) to secure food supply; and (5) to enforce fair prices. Due to the heterogeneous preferences the CAP was highly controversial, however, and was officially launched only in 1962, when the "European Agricultural Guidance and Guarantee Fund" was established, which provided money for the market regimes and structural aid. To explain this integration outcome, Moravcsik presents an extensive analysis of the preferences and bargaining process (Moravcsik 1998, chapter 3; Moravcsik 2000). He shows that the CAP was important for France because it was a surplus producer and exporter of agricultural products and thus interested in preferential access to the other member states' markets. Germany was an agricultural importer, supported its less competitive farmers strongly, and was interested in maintaining its high support prices. France "most intensely favored liberalization of commodities trade within a preferential European zone with modest support prices", but "strongly opposed agricultural trade liberalization in the GATT". Germany objected to internal liberalization "unless very high common support prices were paid", however "was prepared to make GATT concessions" (Moravcsik 1998: 161). These seemingly contradictory positions could be accommodated by choosing the "right" policy instrument: high level price support became the basic strategy of the CAP, satisfying farmers' interests at the expense of European consumers and taxpayers, as well as third countries, who all had to pay for the high prices.

During three decades, the major policy instrument remained price support: common minimum product prices for the European Economic Community (EEC) market, tariffs on agricultural imports, export subsidies for EEC farmers, and direct market interventions, i.e., the community buying oversupply from EEC farmers. This policy lead to food prices above world market level, high stocks in food (the "butter mountains" and "milk lakes"), and became increasingly expensive. The CAP was responsible for more

\footnotetext{
${ }^{3}$ Eurostat: https://ec.europa.eu/eurostat/statistics-explained/index.php?title=File:Gross_value_added_at_ current_basic_prices,2008_and_2018_(\%25_share_of_total_gross_value_added)_FP19.png (last accessed $\overline{5}$ Oct 2019); European Commission: https://ec.europa.eu/agriculture/sites/agriculture/files/rural-areaeconomics/briefs/pdf/08_en.pdf (last accessed 5 Oct 2019).
} 
than two thirds of the EEC budget (e.g. 71\% in 1984). In spite of this protectionist policy, the number of farms decreased steadily, a trend still present today. Moreover, the production oriented support favored large farms over smaller ones.

\subsection{The CAP's reforms}

While reform ideas were present from the beginning within the European Commission (e.g. the Mansholt plan of 1962 pointing out the problems of the price support system; cf. Moravcsik 1998: 211ff.), they met with fierce resistance from the farmers. During the 1980s, however, pressure to undertake first steps of reform became strong enough due to four developments. First, the budget: overproduction had simply become too expensive, which led member states to use the emergency brake. They introduced a quota on dairy products in 1984 and a general ceiling on expenditures to farmers in 1988. Second, growing heterogeneity: with the UK and Scandinavia several countries critical of price support had become members. In the early 1990s, in view of the Eastern enlargement, it became clear that the price support policy would no longer be viable. Third, institutional change: the move from unanimity to qualified majority voting after the Single European Act gave the critical members and the Commission more weight in decision-making. Fourth, international pressure: the European market was the most protectionist in the world, leading to disputes with other large agricultural markets, such as the US, and to a lack of legitimacy towards the less developed world. During the Uruguay round, negotiations in the framework of GATT and WTO pushed the Europeans towards reforming the basic principles of their policy (Roederer-Rynning 2011; Daugbjerg 2017; Daugbjerg and Feindt 2017; Garcia-Duran et al. 2018).

As a consequence, the MacSharry reform of 1992 was the first serious attempt to reduce support and to decouple income support from price support. Intervention prices for agricultural commodities were substantially decreased in successive steps; at the same time direct payments were introduced to compensate farmers if they withdrew land from production; other measures encouraged afforestation, environmental protection and early retirement. Further reforms in 1999 (Agenda 2000), 2003 (Fischler Reform) and 2008 (Health Check) moved the CAP into the same direction, with a shift from price to income support. Import and export subsidies were lowered; the milk quota was finally abolished in 2016; direct payments increased. Whereas direct payments were based on production during the first decades of reform, this has been gradually shifted towards subsidies that are conditional on environmental performance (although the true "green" intentions are disputed, cf. Alons 2017).

To be sure, whereas CAP has, first, moved away from distortion of international markets and, second, the level of protection is lower, it is currently still a policy that protects farmers by direct subsidies. In 2017, $70.6 \%$ of the CAP expenditures are direct payments and only $5.1 \%$ are devoted to market measures (the remaining $24.3 \%$ are spent on rural development). ${ }^{4}$ The decrease of the share of the agricultural expenditures in the EU budget from about 70 to about $40 \%$ may serve as an indicator of the second effect.

\footnotetext{
${ }^{4}$ European Commission, Directorate General for Agriculture and Rural Development 2018: https://ec.europa. eu/agriculture/sites/agriculture/files/statistics/factsheets/pdf/eu_en.pdf (last accessed 31 March 2019).
} 


\subsection{Differentiated integration in CAP}

Before we develop our theory on the demand and supply of differentiations from CAP legal acts, we need to clarify to what the differentiations substantially extend. A differentiation implies in general that a country wants to deviate from a rule in a legal act. The deviations usually extend to the permanent or temporary exemption from a rule for a certain country or a group of countries. The kind of rules affected may vary widely in detail as the examples below show. We start with one basic assumption that will later allow us to determine the direction of the hypotheses:

Basic assumption A differentiation from a rule in a CAP legal act will in general be intended to protect farmers in the respective member state from the anticipated effect of the rule.

We justify this assumption with the fact that the CAP moved gradually away from its price support policies during its reform history and in consequence, EU legal acts in the area of CAP changed in kind after 1992 towards standard-setting. In a first phase after 1992, support prices were gradually reduced by legal acts. Later on, legal acts were no longer setting prices. They were mostly concerned with product or production standards and direct payments and only to a small degree with market regimes. Of the 407 CAP legal acts in our dataset during the period from 1993 to 2012, 42 have differentiated rules. Of these, 24 are concerned with standards, eight with compensation payments, three with quotas, only one refers to tariffs, and six to diverse other topics. The product and production standards relate to product classification, consumer safety, (animal) health and environmental, but also agro-technical issues. Compensation payments are conditional on requirements related to environment needs and rural development.

To illustrate such regulations and differentiations and their intended protectionist effect, we give a number of examples. As a typical production standard, directive 1999/74/EC regulates minimum standards for the protection of laying hens. There are temporary derogations for six countries from the Eastern cohort: they may use smaller cage sizes. For a product standard, regulations 1601/91/EEC and 2061/96/EEC forbid the use of the colorant Tartrazin in certain beverages containing wine. Italy received an exemption for wine products exported to third states. Regulation 3220/84/EEC classifies pig carcasses. Latvia has a permanent derogation, allowing the use of a different method of estimating the weight of carcasses, justified by a different tradition of trading (without certain parts). Regulation 2529/2001/EC provides rules for compensation payments in beef and lamb production. The UK was in addition granted the right to introduce import licenses for beef and lamb from the EU and third states to protect these products on the Isle of Man (2006/138/EC). Regulation 952/97/EC provided rules for subsidizing producer groups or associations, to be applied in nine member states and to certain products, with deviating rules for Portugal. Regulation 670/2003/EC on measures concerning ethyl alcohol of agricultural origin (e.g. fruit brandy) forbids national aid for the production of such alcohol. Germany received a temporary derogation until 2010 permitting aid to small producers in the framework of the German Alcohol Monopoly.

The change from price support to direct payments implies great structural change and adaptation cost in the farming sector. Further, the new environmental requirements and standards usually raise production costs. Farmers negatively affected by such 
regulations might therefore resist to them. The protests by farmers in Germany and the Netherlands against stronger environmental regulation in 2019 and 2020 are a case in point. $^{5}$ In consequence, the farm lobby of a country may ask the government to object the rules or to raise a demand for DI. For example, in the mentioned case of ethyl alcohol, German farmers' associations lobbied for an extension of the derogation until $2017,{ }^{6}$ which was granted for small distilleries after some negotiations with the EU institutions (1234/2010/EU).

Given that the CAP is now mainly concerned with compensation payments and the regulation of products and production processes, we conclude that DI is mostly demanded from member states wanting to keep the costs of structural change and EU regulation for their farmers as low as possible, and to keep a certain level of protection for their agricultural sector for at least some time.

\section{A liberal theory of preferences and decision-making in CAP}

\subsection{The liberal intergovernmentalist framework}

For our goal to analyze the drivers of differentiation of legal acts in CAP, we need to take into account both the demand for an opt-out from a certain policy as uttered by the national governments, and the supply of such a differentiation by the European institutions during the process of negotiating a legal act. Our theory of differentiation in EU policy-making builds on the liberal intergovernmentalist framework (Moravcsik 1998). We briefly present the framework before we describe how we adapt it to our subject, DI in CAP.

Liberal intergovernmentalism provides an actor-centered rationalist explanation for European integration and a political economy model of preference formation and decision-making. The model starts with two assumptions: states are actors and they are rational, i.e., they maximize or satisfice their utility (Moravcsik and Schimmelfennig 2009). According to the model, integration choices are made in two stages. In the first stage, called national preference formation, societal groups articulate their political demands and put pressure on their governments. Re-election-seeking governments then aggregate the societal demands, taking into account the various often conflicting - societal interests. This way, national governments generate consistent issue-specific preferences. In the second stage, they defend these preferences in interstate negotiations in the European Council. Moravcsik suggests a bargaining theory in which the outcome of the process depends on relative bargaining power and bargaining dynamics such as credible commitments, veto threats, side payments, package deals, and compromise-seeking. The outcome, in the original model, is the choice of European institutions.

Moravcsik develops his theory in The Choice for Europe where he analyses five major steps in European integration using his analytical framework and applying it to

\footnotetext{
${ }^{5}$ https:/www.rbb24.de/wirtschaft/thema/2020/gruene-woche/beitraege/bauern-protest-gruene-woche-berlinbrandenburg.html; https://www.politico.eu/article/angry-dutch-farmers-swarm-the-hague-to-protest-greenrules/ (last accessed 17 January 2020).

${ }^{6}$ https://media.bayerischerbauernverband.de/89/528489.pdf (last accessed 10 October 2019).
} 
three member states for the stage of national preference formation. The outcomes are constitutional choices, the "grand bargains", implying some contextual restrictions (or scope conditions), such as unanimous decision-making of the negotiating governments. This was later criticized: the theory would not explain everyday decision-making and not account for the role of EU institutions as only bargaining over the preferences of governments was in the focus (see Kleine and Pollack 2018 for a recent and excellent discussion of the debates on liberal intergovernmentalism). Furthermore, the "liberal" points to a major claim of Moravcsik: he argued that the national preferences were mostly determined by economic interest, not by geopolitical strategy or by great ideas and ideological goals. This was sometimes mistaken as a claim that always economic interests or producer interests prevail. However, the basic model is open as to which preferences the governments form, as this is issue-specific (Moravcsik and Schimmelfennig 2009: 70).

For our research, we contextualize the theory of liberal intergovernmentalism to better fit our subject, the DI in CAP. While we are in accordance with its basic assumptions and its two stage model of national preference formation and collective bargaining, we deviate in five respects from the original model:

1) Moravscik intended to explain major European integration events at the constitutional level, and his outcome variable were the "grand bargains". Our explanandum are everyday-EU agricultural policy choices, the rules and regulations laid down in secondary law. More specifically, we are not interested in the policy choices themselves but in the exemptions a member state negotiates in the bargaining phase.

2) In contrast to Moravcsik's analysis of the CAP introduction around 1960 (2000; 1998, chapter 3), we analyze the period after 1993. Membership has increased and agricultural preferences as to market liberalization and farmers' protection are differently distributed in the Council. It is important to note, however, that the national preferences are not necessarily less protectionist. Governments just favor different instruments to protect their agricultural sectors.

3) More member states and increasing heterogeneity had consequences for collective decision-making in the Council. Decisions on legal acts in agriculture followed the Consultation procedure and qualified majority voting. Governments used to take decisions unanimously in a search for consensual outcomes (Kleine 2013: 91) after the Luxemburg Compromise, at least until the Single European Act (and could this way override the Commission with its different preferences, see above). At the end of the 1980s, however, agricultural decisions were increasingly taken in explicit votes by qualified majority as stipulated in the treaty (Roederer-Rynning 2011: 21). That is, the closing rule after a bargaining process is no longer unanimity but qualified majority. Therefore we use voting power in our model, next to bargaining power. Whereas with unanimity every member has a veto, with qualified majority the pivot has the veto power. It is important to note, however, we still assume classical bargaining dynamics in the Council before the vote is taken.

4) We use the terminology that is by now common in the literature on DI (Leuffen et al. 2013; Holzinger and Tosun 2019). That is, the first stage in Moravcsik's model corresponds to the formation of the demand for differentiation by a national government; the second step corresponds to the supply-side of differentiation and 
its delivery after successful negotiations in the Council of Ministers for Agriculture.

5) Finally, there is a difference in research strategy: Moravcsik $(1998,2000)$ presents a qualitative analysis of five cases for three countries. We aim at a statistical analysis of all member states and a long period of time, i.e., many policy choices and differentiations. This implies we have to look for approximations in measurements and we cannot closely follow the complex causal relationships we theoretically assume.

In accordance with the model, we develop four hypotheses on demand and supply of differentiation to CAP legal acts. The first hypothesis relates to the level of sectorspecific national protectionism to account for the political influence of the agricultural lobby, the second hypothesis relates to the government's receptiveness through party ideology, and the third to the voting and bargaining power of the members states in the Council. The fourth hypothesis deals with the interaction of demand and supply.

It is important to note that the first two hypotheses relate to the demand for differentiation, as raised by the agricultural sector and the national governments. As no data on demand and governmental preferences exist, we cannot measure them directly, however. We therefore approximate demand by structural indicators of national agricultural lobbyism and national politics. We implicitly assume that across countries, these factors should lead to a demand for DI that national governments will communicate at the EU level. For the supply hypotheses, we assume member state capacities to influence the supply decision at the EU level, which can be directly measured by bargaining and voting power. We phrase all hypotheses in terms of "realized differentiations" as our dependent variable. Realized differentiations measure the outcome of demand and supply factors. We can safely assume that the delivery of differentiations presupposes a demand for it, and there will be no differentiations supplied without any demand. The likelihood of delivery of differentiations is to a great degree influenced by demand, but also by the government's negotiation capacities. Whereas we expect a direct effect of both, we also consider their interaction in order to explain realized differentiation.

\subsection{National demand for differentiations in CAP}

The first stage of the model pertains to the formation of a national demand for differentiation. Just as Moravcsik does in his case analyses when he first reports the types of societal interests (geopolitical, economic) and then "the domestic decision" (1998, e.g. p. 201), we identify two processes in the preference aggregation: organized societal interests lobbying the government; and the government forming a national preference by taking into account societal demands and its own interests.

\subsubsection{Sector lobbyism: Agricultural protectionism}

First, societal interests are the key drivers of national preferences. Societal demands might include lobbying from the agricultural sector, on the one hand, and from consumers and taxpayers, on the other hand. Agricultural interests are very specific in their representation. There is a general ability of the agricultural lobby to push their 
interests through at the expense of all others (e.g. consumers, taxpayers, third states). We base our argument on an Olsonian collective action approach (1972, Olson 1985). He demonstrated that although agricultural producer groups vary in size and homogeneity of interests, they all have a common interest in protectionism at the expense of antagonistic groups. Accordingly, in most EU member states, agricultural interests have a very high level of organization with a medium to low number of members (Wonka et al. 2010). This makes them very efficient in pursuing their interests. As Moravcsik and Schimmelfennig (2009: 77) state: "Farmers' associations have intense preferences, are highly organized, and exercise a strong influence on governments".

Consumer and taxpayer interests are involved because the price support policy of the traditional CAP worked clearly to their disadvantage. Following Olson's (1971) theory of collective action consumers and taxpayers are not well organized in general. They have little capacity to oppose rent seeking behavior of farmers (Olson 1985). Moreover, in the case of the CAP, the cost to consumers and taxpayers is not easy to recognize, food prices are accepted and a country's contribution to the EU budget is not particularly visible. In consequence, these interests are rarely even articulated in the national political process (Olson 1985; Steen 1981).

The effectiveness of the agricultural sector to push its interests through against other interests in a society is captured by the level of sector-specific protection in a country. If we see protectionism as an active engagement of the nation state to support its agricultural sector, we can interpret the level of protectionism as an indicator of the political strength of the agricultural sector and of its demand for protection. We assume that more protectionism in a country mirrors the will of decision-makers to support the national agricultural sector. This political will should also be reflected in a higher number of differentiations.

Hypothesis 1 The higher the level of agricultural protectionism in a member state, the higher the extent of realized differentiations of this state.

\subsubsection{Government receptiveness: Party bonds}

Demand from the agricultural lobby is not sufficient for explaining member state preferences for differentiation. While interest groups usually voice the demand, governments that represent the state at the European level must also be receptive. Only if agricultural interests are salient to politicians, they will start negotiating about CAP differentiations for their constituency. Salience is generally the importance of an issue for decision-makers as compared to other issues (Leuffen et al. 2014; Beyers et al. 2018). The salience of a given issue to a democratic government is influenced by interest group lobbyism but also by electoral incentives.

Again, agricultural electoral politics is very specific: farmers are traditionally loyal voters of conservative parties. There is a strong anecdotal tendency to assume that if conservative parties hold the government, they support the agricultural interests stronger than liberal or social-democratic parties. This reading emerged at the end of the nineteenth century when voting rights were extended to the general population and consequently conservative parties saw rural households as an important source of votes (Tracy 1989). Swinnen observes that a crucial political strategy of conservative parties in continental Europe was the political organization of the rural areas to create a strong power base and reliable source of votes (Swinnen 2009: 1523). However, the findings 
of theory-driven quantitative studies about this relationship are not straightforward. Dutt and Mitra (2009) conclude that right-wing governments will try to hold protection at a minimum. For left-wing governments, it depends on the share of labor force in agriculture and the mobility of labor if they try to protect agriculture or not. We nevertheless hypothesize that conservative parties are closer to the agricultural sector than left-wing parties and will be more receptive to their demands: whereas conservative parties might lose voters and members if they do not defend farmers' interests, other parties are less affected by such a threat.

Hypothesis 2 The more conservative the government of a member state, the higher the extent of realized differentiations of this state.

\subsection{Supply of differentiation: Negotiations in the Council of Ministers for Agriculture}

As to the supply-side of differentiation, agricultural policy decisions are taken in the Council of Ministers for Agriculture. Whether a member state government can push its demand for a differentiation through depends on its negotiation power which is affected by its political and economic weight and by its voting power. For CAP, the decision rule in the Council is qualified majority, and the legislative procedure was Consultation until 2010, followed by Codecision and the Ordinary Legislative Procedure afterwards. $^{7}$ This implies that for most of our time period the European Parliament did not have a say in CAP. Whether a demand for a certain differentiation could be successfully turned into a "realized differentiation" was solely dependent on the negotiations in the Council. Analyzing Council decision-making is thus sufficient to capture the supply-side of differentiations in in CAP.

Qualified majority voting was always an option during our observation period (Roederer-Rynning 2011; Bailer et al. 2015). Yet the fact that a decision is taken by a final vote does not imply that there are no negotiations before, building on arguments and bargaining dynamics. Apart from tactics such as threats of exit or veto, there are three ways of constructively finding solutions to accommodate heterogeneous interests: First, an issueinternal compromise can be found. Over decades, Commission and Coreper have developed great expertise and ingenuity in proposing such compromises. Second, issue-linkage and package deals can lead to a successful negotiation outcome. Third, and most importantly in our context, exemptions, derogations and all kinds of flexibility can provide ways out of a deadlock.

Nevertheless, in the Council of Ministers negotiations take place under the shadow of the vote. Therefore we assume voting power is decisive for the success in being granted an exemption. Under qualified majority voting, member states have different numbers of votes, roughly according to population size. For bodies with weighted voting, formal analyses use power indices that seek to measure the relative power of governments by calculating their share of pivotal positions, i.e., the likelihood with which they can turn winning into losing coalitions (cf. Banzhaf 1965; Shapley and Shubik 1954).

\footnotetext{
${ }^{7} \mathrm{Cf}$. for background information on CAP decision-making:

http://www.europarl.europa.eu/factsheets/en/sheet/103/the-common-agricultural-policy-cap-and-the-treaty (last accessed 9 April 2019).
} 
But how should voting power affect DI? If we interpret the realization of a differentiation as a function of an actor's capabilities to influence the decision outcome, we should see variance between powerful and weak member states in their ability to achieve a differentiation. Higher shares of pivotal positons, i.e., higher voting power, should enable member states to achieve more differentiations, because they are more often in a situation in which their vote is needed for a winning coalition. They can thus "trade" votes against differentiations. Holzinger and Tosun (2019) argue there is great willingness in the EU Council to grant differentiations because of asymmetric information about the reasons given by member states to justify their demand for differentiations.

Hypothesis $3 a$ The higher the voting power of a member state, the higher the extent of realized differentiations.

As Moravcsik (1998) has claimed, however, the effectiveness of a government to achieve a differentiation during the Council negotiations might also be a consequence of its general bargaining power in the EU's political setting. He argues throughout that the preferences of the three economically strongest member states largely explain bargaining outcomes in EU integration. Thus, even if voting power plays a role, this does not exclude an additional effect of economic strength on bargaining outcomes. The standard indicator used in the International Relations and EU literature (e.g. Magnette 2004: 391; Slapin 2006, 2008; Dür and Mateo 2010: 565; Reinhard et al. 2014) is the economic weight of a country as measured by its gross domestic product (GDP). Countries with higher GDP should be more successful in being granted DI.

Hypothesis $3 b$ The higher the economic bargaining power of a member state, the higher the extent of realized differentiations.

Further, we hypothesize that demand and supply factors will enhance each other's effect on the level of realized differentiation. Only if there is demand for a certain differentiation by a member state, the power of this state versus the other Council members' power comes into play. Therefore we formulate an interaction hypothesis stating that the more power a member state possesses in Council negotiations, the larger the effect of the demand factors on the level of realized differentiations.

Hypothesis 4 For each demand factor, the higher the values for this factor and the higher the power of a member state, the higher the extent of realized differentiations of this state.

\subsection{Controls: Potential alternative drivers of differentiations in CAP}

Following liberal intergovernmentalism, our theoretical model concentrates on sector lobbying, government receptiveness and negotiations in the Council. For control we use a number of complementary or alternative factors that may explain the extent of differentiation member states achieve.

First, we take the structural dimensions of the agricultural sector into account. The substantial preferences of the agricultural lobby might be informed or determined by the structure and competitiveness of this sector in a country. Similarly, a rational and benevolent government might consider a sector's structural attributes before simply accepting a lobby's demand. The most important structural factor should be the sectors' international competitiveness. We use productivity as an indicator for competitiveness. Theoretically, higher productivity of national agricultural sectors should imply higher competitiveness at the international markets and thus greater willingness of the sector to 
accept the new policy of the CAP after the reforms and lower demand for DI. A nation's farm structure is the second characteristic that might have a structural effect on the level of differentiation per country. Large farms might have gained from the production-based direct payments and might have comparative advantages in production, making them more competitive and leading to lower demand for DI.

Apart from direct lobbyism, rational governments might be receptive to agricultural interests also because of political economy considerations. Agriculture can be politically salient because farmers and their employees are also voters. Daugbjerg (2003: 430) and Kim (Kim 2010: 331) argue that losing the support of farmers was unacceptable to the French government in previous CAP negotiations because of their voting power. A higher share of the labor force in agriculture, and thus of potential voters, makes the CAP more salient to government. As an effect, they could try to please their constituencies by negotiating differentiations. This argument is different from hypothesis 2 on a loyalty relationship between farmers and conservative parties, as it assumes rational vote-seeking parties in general (see Dutt and Mitra 2009 for left-wing governments).

\section{Empirical strategy}

\subsection{The dependent variable: Differentiations in CAP}

The data for our dependent variable uses EU secondary law, i.e., directives and regulations, which the EU has adopted between 1993 and 2012. We rely on the EUDIFF2 dataset (Duttle et al. 2017). This dataset identifies whether a legal act explicitly exempts a given country from its legal rules. ${ }^{8}$

Based on the population of all acts, the outcome of interest is whether a country realizes a differentiation for the given act. There is one additional specification: As Winzen (2016) reports, $60 \%$ of opt-outs originate later in the lifetime of the laws and not in the first year. Thus, we face two different coding options: To assign the differentiation to the country-year when it was first realized or to assign it to the country-year where the act came into force. Based on the focus of the paper to model the preference formation and negotiation stage of the decision, we opt for the possibility to assign the differentiation to the year when the act came into force.

The main outcome variable then is the number of differentiations in new legislation a country realizes in a given year in the CAP. Within our observation period, we have a universe of 407 new CAP legal acts. Within these new acts, we observe 122 countryyears with a differentiation.

We limit our study to the years 1993-2012. This solves two problems: In the first years of the 1990s, Germany is a major differentiation outlier as a result of legislative perturbations caused by reunification. Thus, it makes sense to omit these years.

\footnotetext{
${ }^{8}$ We do not make a difference regarding the importance of the legal rules that are covered by such an opt-out. This can be seen as a problem since some differentiations are presumably more important than others. At the same time, however, EU secondary legislation is highly detailed and issue-specific. Convincing and transparent criteria to judge whether a given differentiation is important or not (not to speak of how important) are, as far as we are aware, not available. Against this background, measuring the presence or absence of differentiations is, though not perfectly precise, nonetheless a clear indicator that a law does not fully apply to a given country.
} 
Furthermore, the MacSharry reform took place in 1992, so 1993 is the first year under the new regime of direct payments instead of prize support.

The final dependent variable contains the number of differentiations in new CAP legislation for 12 member states from 1993 to 2012, for the EFTA cohort from their accession 1995 to 2012, for the ten member states of the first Eastern enlargement round from 2004 to 2012, and for Romania and Bulgaria from 2007 to 2012. As the visualization of the different accession cohorts in Fig. 1 shows, the number of differentiations in new legislation shows great variation over time. We want to highlight three key aspects: First, we can observe some years where no differentiation at all is realized $(1994,1996,1998,2011,2012)$. Second, we can see that especially for the earlier years, the cohorts realize almost identical numbers of new opt outs. This clear trend diminishes in the 2000s. Third, compared to the development of all differentiations in secondary legislation (cf. Duttle 2016), one outstanding feature of the CAP is the relatively low realized differentiations of the Northern accession cohort (the UK, Denmark, and Ireland). Whereas these countries realize significantly more differentiations if all policy fields are considered, especially in the 2000 s after the introduction of the Euro and the Eastern enlargement, the Northern cohort has no extraordinary pattern in CAP differentiation.

\subsection{Method}

Our substantive interest in this paper lies in explaining the variation of realized CAP differentiations over time and across countries. To this end, our dependent variable counts the number of DIs per country per year. ${ }^{9}$ As fig. 1 already foreshadowed, our data contains an excessive number of observations with no DIs in a year, i.e. our data is zero-inflated. To adequately model this set-up, we analyze our time-series and crosssectional data based on a Poisson model with random effects. The additional advantage of the Poisson approach is that the conditional maximum likelihood estimators are fully efficient and even robust to distributional misspecification (Wooldridge 2002). Random effects were chosen because this enables us to test both for the effect of demand within a country and between all countries. We control for some unobserved underlying trends by introducing year dummies for every year where an enlargement round happened. ${ }^{10}$

\subsection{Independent variables}

We opt for the level of prize distortion as a good measure for protectionism. As outlined above, protection in the EU agricultural sector arises from two components: prize support and income support, with prize support fading out during the 1990s and income support rising. It is important to note, however, that both types of subsidy distort prizes. While income support does not distort world product markets, it still indirectly supports domestic prizes, in particular if income support is quantity-related, as it long was and still is in the EU. The rate of assistance captures how much a national

\footnotetext{
${ }^{9}$ Since we model decisions on new legislation for every year, we opted against the introduction of a lagged dependent variable. We assume that the negotiated differentiations in a given year do not depend on past decisions.

${ }^{10}$ We additionally control for the potential underlying time trends based on the development of the CAP in general by introducing year-dummies for CAP reforms. The results can be found in Appendix 1 .
} 


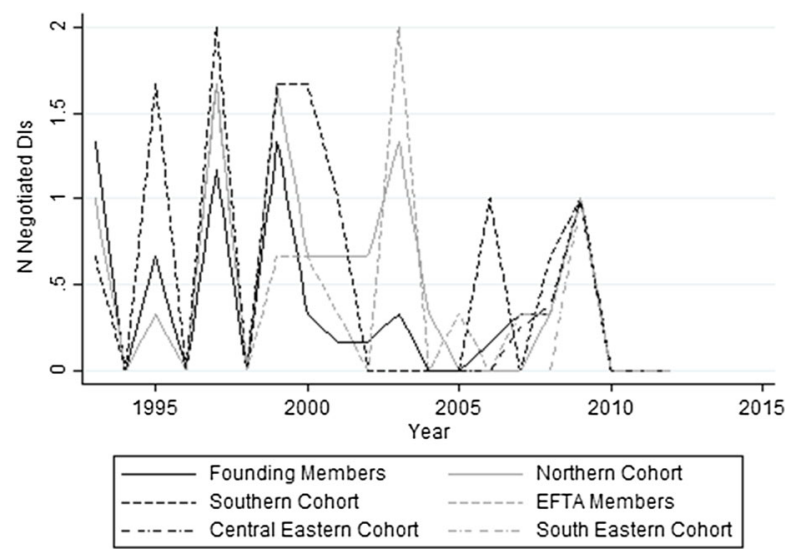

Fig. 1 Mean number $(\mathrm{N})$ of realized differentiations in new legislation for accession cohorts

agricultural market is actually subsidized by political intervention. This measure and the data on price distortion in agriculture has recently been developed by the World Bank (Anderson and Valenzuela 2008). Hereby, the Nominal Rate of Assistance (NRA) is computed as the percentage by which government policies have raised (or lowered) gross returns to farmers compared to a situation in which governments have not intervened (variable: protectionism). If governments have raised gross returns, i.e., if agricultural production was subsidized, then protectionism $>0$, while protectionism $<0$ if governments have effectively taxed agriculture.

Naturally, one would think that under the CAP, farmers from different member states are treated equally. But even in the times of intervention prices, with the same export prices across the EU, the extent of subsidy they implied varied across farms and countries because of different conditions of production. Also today, the CAP may play out differently depending on national agricultural structure, such as landscape, type of land, type of products, size of farms, etc. Further, governments still have quite some leverage in implementing CAP domestically, and leeway to support and protect agriculture on the national level. Agricultural prize distortion grasps not only EU, but also national support and varies greatly across the EU. All EU member states have a positive value indicating government support or protectionism; however, there exists huge cross-country variance from almost no prize distortion (Bulgaria in 2011, .009) to radical raise of prize returns (Ireland 1999, .932) which can be seen in Table 1.

We decided to use the political ideology of governments to gauge political receptiveness. We see the classical left-right scale as a good overall approximation of the political will to support farmer's interest, with more conservative governments being more in favor of these issues. The political ideology of the governments in Council negotiations is measured by the average cabinet ideology as introduced by Armingeon et al. (2013) (variable: ideology). Political parties are coded on a 5 point scale with higher values indicating a more conservative government.

Turning to the supply-side - negotiation and voting in the Council of Ministers - we use the Shapley-Shubik index as the measure of voting power (variable: ShapleyShubik index). In contrast to the Banzhaf index, the Shapley-Shubik index builds on all permutations of potential winning coalitions, taking the sequence of joining a coalition into account. We evaluate this procedure as more adequate for capturing the 
Table 1 Overview and descriptive statistics of all variables

\begin{tabular}{lllll}
\hline Variable & Mean & Min & Max & Source \\
\hline Number of DIs in new acts & 0.69 & 0 & 14 & Own collection \\
Protectionism & 0.26 & 0.01 & 0.93 & World Bank \\
Ideology & 2.67 & 1.00 & 5.00 & CPDS \\
Shapley-Shubik index & 5.15 & 0.82 & 13.42 & Antonakakis et al. \\
GDP (in billions) & 580.22 & 5.12 & 3628.11 & Eurostat \\
Productivity & 100.69 & 76.27 & 120.88 & FAO \\
\% large farms & 12.63 & 0 & 38.70 & Eurostat \\
\% workers in agriculture & 6.07 & 0.60 & 21.60 & FAO \\
\hline
\end{tabular}

political process in the Council. We take the index values from Antonakakis et al. (2016). In line with the literature, we use economic strength as a second dimension of power in Council negotiations (variable: GDP). ${ }^{11}$

We presented three controls to take into account potential alternative explanations of DI negotiation success. We use the agricultural productivity index (variable: productivity) of the Food and Agriculture Organization of the UN (FAO) to measure the competitiveness of the agricultural sector in a country. The second dimension of sector structure is the share of large farms in a country as provided in the Eurostat dataset (variable: \% large farms). Larger farms are generally assumed to be more productive. We use the share of farms with a size larger than 50 ha to measure this dimension of competitiveness. ${ }^{12}$ To gauge the salience of the agricultural sector to national governments, we use the share of workers in the agricultural sector from the FAO (variable: workers in agriculture). ${ }^{13}$ Table 1 gives the descriptive statistics for all variables.

In all models, we use independent variables that are lagged by one year. This choice is justified by the fact that the political process of negotiating opt-outs takes time, so we assume that the most realistic representation of the preference formation and negotiation process is one where the information about preferences for opt-outs come from the structural features as they were in the previous year. In all models, we additionally control for the structural preconditions of the national agricultural sector (agricultural productivity, share of large farms) and the sector salience to the government (share of agricultural workforce).

\section{Findings}

In this section we first report results for the relationship between our measures of member states demand and differentiation in the CAP. We then look at the second level

\footnotetext{
${ }^{11} \mathrm{https} / /$ ec.europa.eu/eurostat/statistics-explained/index.php/National_accounts_and_GDP (last accessed 5 October 2019). For robustness, we tested also a number of other indicators that might measure bargaining power: the size of net contributions of member states, their agricultural GDP, and their intra-EU trade (in total and as share). None of them shows any significant results. Cf. Appendix 2.

$12 \mathrm{https} / /$ ec.europa.eu/eurostat/de/web/main/home (last accessed 5 October 2019).

${ }^{13} \mathrm{http}: / /$ www.fao.org/statistics/en/ (last accessed 5 October 2019).
} 
of the liberal intergovernmentalist theory - interstate bargaining - and analyze if a member state's power acts as a main effect and mediator in the explanation of the realized level of differentiations that a country achieves.

\subsection{Preferences for differentiations: The demand side}

Does sectoral lobbyism and governmental receptiveness within a member state influence the level of differentiation in the CAP? We introduce the two models for the respective domestic drivers separately. Table 2 includes all results from our statistical analysis.

The first dimension of demand is the sectoral ability to lobby for its agricultural interests. We conjectured that the actual level of agricultural prize distortion should have a positive effect on the number of differentiations. And indeed, model 1 shows this positive and strongly significant effect. In line with H1, if farmers lobbied successfully for a high rate of protectionism, i.e., if they achieved a high level of prize distortion in their favor, they will also realize more differentiations. The demand for protection advocated by strong agricultural lobby groups and materialized in already established benefits is a good predictor for the number of opt-outs a given country receives.

Beyond sector demand, we developed a political argument why national governments should vary in their level of receptiveness towards agricultural interest based on political ideology. We hypothesized that conservative governments will negotiate with higher intensity for differentiation in agriculture, which should lead to a higher number of opt-outs. In line with this theoretical expectation (H2), the covariate that captures party ideology in model 2 shows a significant effect in the right direction: under conservative governments, more opt-outs are realized in new legislation.

We take this as evidence for our basic assumption that differentiations can be seen as another way of protecting the national agricultural sector. In addition, our results in the controls suggest that the structure of farms and the share of workforce in the agricultural sector are not related with the number of opt-outs. Contrary, the "competitiveness" measure shows that more competitive national agricultural sectors demanding and realizing less DI. ${ }^{14}$

\subsection{Negotiating differentiation in the COUNCIL: The supply side}

Once a government prefers a differentiation, this preference has to be translated into an actual opt-out in the Council of Ministers. We argued that the capability of member states to achieve the desired outcome depends on their voting power within Council negotiations and their economic power. For a linear test of this assumption, we introduce the Shapley-Shubik index as covariate in model 3 and GDP in model 4 of Table 2. In contrast to previous studies on differentiated integration in the EU (Duttle 2016), we find support for H3a that the voting power of a country is positively related

\footnotetext{
${ }^{14}$ We tried to control for unobserved events and other clusters. The year dummies introduced for the enlargement rounds show a significant enlargement effect only in 2004 (Eastern enlargement 1). Contrary to common wisdom, there was less DI in the CAP in that year. The year dummies for the reform years in Appendix 1 show that the Agenda 2000 and the Fischler reform caused indeed more DI, but the effects for our main independent variables stay robust.
} 
Table 2 Effects of national demand and EU supply variables on the level of realized differentiations in CAP legal acts, 1993-2012

\begin{tabular}{|c|c|c|c|c|c|}
\hline & (1) & (2) & (3) & (4) & (5) \\
\hline DV: Number realized DIs & $\begin{array}{l}\text { Sector } \\
\text { Lobbyism }\end{array}$ & $\begin{array}{l}\text { Government } \\
\text { Receptiveness }\end{array}$ & $\begin{array}{l}\text { Voting } \\
\text { Power }\end{array}$ & $\begin{array}{l}\text { Bargaining } \\
\text { Power }\end{array}$ & Full Model \\
\hline L. protectionism & $\begin{array}{l}1.73 * * * \\
(0.32)\end{array}$ & & & & $\begin{array}{l}1.53 * * * \\
(0.30)\end{array}$ \\
\hline L. ideology & & $\begin{array}{l}0.18 * * * \\
(0.07)\end{array}$ & & & $\begin{array}{l}0.15 * * \\
(0.07)\end{array}$ \\
\hline L. Shapley-Shubik index & & & $\begin{array}{l}0.06^{* * * *} \\
(0.02)\end{array}$ & & $\begin{array}{l}0.03^{*} \\
(0.02)\end{array}$ \\
\hline L. GDP & & & & $\begin{array}{l}0.00 \\
(0.00)\end{array}$ & \\
\hline L. productivity & $\begin{array}{l}-0.03 * * * \\
(0.01)\end{array}$ & $\begin{array}{l}-0.02 * * * \\
(0.01)\end{array}$ & $\begin{array}{l}-0.02 * * \\
(0.01)\end{array}$ & $\begin{array}{l}-0.01 * \\
(0.01)\end{array}$ & $\begin{array}{l}-0.03 \text { *** } \\
(0.01)\end{array}$ \\
\hline L. \% large farms & $\begin{array}{l}0.00 \\
(0.01)\end{array}$ & $\begin{array}{l}0.01 \\
(0.01)\end{array}$ & $\begin{array}{l}0.00 \\
(0.01)\end{array}$ & $\begin{array}{l}0.00 \\
(0.01)\end{array}$ & $\begin{array}{l}0.00 \\
(0.01)\end{array}$ \\
\hline L. \% workers in agriculture & $\begin{array}{l}0.02 \\
(0.01)\end{array}$ & $\begin{array}{l}0.02 \\
(0.02)\end{array}$ & $\begin{array}{l}0.03 \\
(0.02)\end{array}$ & $\begin{array}{l}0.03^{*} \\
(0.02)\end{array}$ & $\begin{array}{l}0.02 \\
(0.01)\end{array}$ \\
\hline 1995 EFTA enlargement & $\begin{array}{l}0.25 \\
(0.24)\end{array}$ & $\begin{array}{l}0.69 * * * \\
(0.23)\end{array}$ & $\begin{array}{l}0.38 \\
(0.27)\end{array}$ & $\begin{array}{l}0.62 * * \\
(0.24)\end{array}$ & $\begin{array}{l}0.22 \\
(0.25)\end{array}$ \\
\hline 2004 Eastern enlargement 1 & $\begin{array}{l}-1.91 * * \\
(0.92)\end{array}$ & $\begin{array}{l}-1.68 * \\
(0.90)\end{array}$ & $\begin{array}{l}-1.80 * * \\
(0.90)\end{array}$ & $\begin{array}{l}-1.71 * \\
(0.91)\end{array}$ & $\begin{array}{l}-1.86^{* *} \\
(0.90)\end{array}$ \\
\hline 2007 Eastern enlargement 2 & $\begin{array}{l}-0.45 \\
(0.53)\end{array}$ & $\begin{array}{l}-0.61 \\
(0.53)\end{array}$ & $\begin{array}{l}-0.56 \\
(0.52)\end{array}$ & $\begin{array}{l}-0.63 \\
(0.52)\end{array}$ & $\begin{array}{l}-0.41 \\
(0.53)\end{array}$ \\
\hline Constant & $\begin{array}{l}1.70 * * * \\
(0.55)\end{array}$ & $\begin{array}{l}0.12 \\
(0.75)\end{array}$ & $\begin{array}{l}0.21 \\
(0.67)\end{array}$ & $\begin{array}{l}0.28 \\
(0.78)\end{array}$ & $\begin{array}{l}1.01 * \\
(0.54)\end{array}$ \\
\hline Observations & 309 & 320 & 320 & 320 & 309 \\
\hline $\mathrm{N}$ Countries & 24 & 25 & 25 & 25 & 24 \\
\hline N Years & 20 & 20 & 20 & 20 & 20 \\
\hline
\end{tabular}

Standard errors in parentheses; ${ }^{*} p<0.1,{ }^{* *} p<0.05,{ }^{* * *} p<0.01$; Time series cross-section, DV: count, Poisson regression

to the level of differentiation: the more voting power a member state has in CAP Council negotiations, the higher the numbers of new differentiations. Alternatively, we use the economic power of a country as a determining factor of bargaining success. We therefore test in Model 4 the effect of GDP on the number of granted opt-outs. Our analysis does not support the claim of $\mathrm{H} 3 \mathrm{~b}$, since we find no significant association between GDP and the number of opt-outs. ${ }^{15}$

As conjectured above, demand and supply factors may enhance each other's effect on the level of realized differentiation (H4). We hypothesize that the more power a

\footnotetext{
${ }^{15}$ Appendix 2 presents the additional results for other measures of bargaining power. As already foreshadowed, none of them shows a significant relationship.
} 
member state possesses in Council negotiations, the larger the effect of our demand factors on the level of realized differentiations. For an empirical test, we interact our two demand predictors with the Shapley-Shubik index and GDP. ${ }^{16}$

We find no significant interaction effect between voting power and the demand factors. More voting power does not increase the number of differentiations if demand in terms of protectionism or conservative ideology increases in a country. Whereas the effect for protectionism is totally absent, as the upper panel of fig. 2 shows, party ideology has even a negative - but non-significant - interaction effect with voting power. Turning to the economic power of a country, our hypothesized interaction between bargaining strength and farmer demand at home unfolds for the protectionist measure: economically stronger countries realize more DI when protectionism expects them to do so. However, for political ideology, the effect is not significant and again reversed in its direction.

We observe that voting power in the second stage of the liberal intergovernmental framework does not moderate the influence of the domestic demand factors on differentiation, whereas economic strength does. For a better understanding of these effects, we visualize ideal types of countries from our models with the interaction terms. One country is modeled to be weak (with a Shapley-Shubik Index or GDP value indicating the $10 \%$ percentile of the distribution) and one strong (supply values of the 90\% percentile). Fig. 3 shows, for purposes of illustration, the marginal effects of the level of protectionism for the two ideal values of the Shapley-Shubik index and GDP. ${ }^{17}$

The results in fig. 3 give us an indication why voting power in the Council has no significant interaction effect with national demand. We can see that the intercepts between countries with high and low voting power differ (countries with more power realize more DI, the significant Shapley-Shubik Index in our previous models), but the slope for the two ideal types runs parallel. Voting power is important, but not more important with more demand, what we would have assumed. This stands in contrast to the results for economic strength, as visualized in the right panel of fig. 3. Here, we can see two different slopes: The one increasing slightly for economically weak countries, and the other increasing more strongly for the prediction of a powerful country. Ultimately, we see a statistically significant difference in these two slopes. Economically stronger countries realize more DIs at the bargaining stage if there is strong national demand. With no demand at home, they do not bargain differently from economically weak countries.

If we combine the results from the different analytical stages, we can conclude:

(1) In line with the predictions of liberal intergovernmentalism, political demand factors affect governmental preferences in EU negotiations. We find that more protectionism of the agricultural sector (lobbying success) and a party ideology in favor of farmers are associated with more DI in the CAP.

(2) At the bargaining stage in the Council, our results indicate that stronger voting power leads to more realized DI, as predicted. Contrary, the bargaining power as measured by the economic strength of a country, has no direct relationship with realized DI.

${ }^{16}$ We provide the regression tables in Appendix 3.

${ }^{17}$ Figures for the predictive margins of the interactions with political ideology can be found in Appendix 4 . 

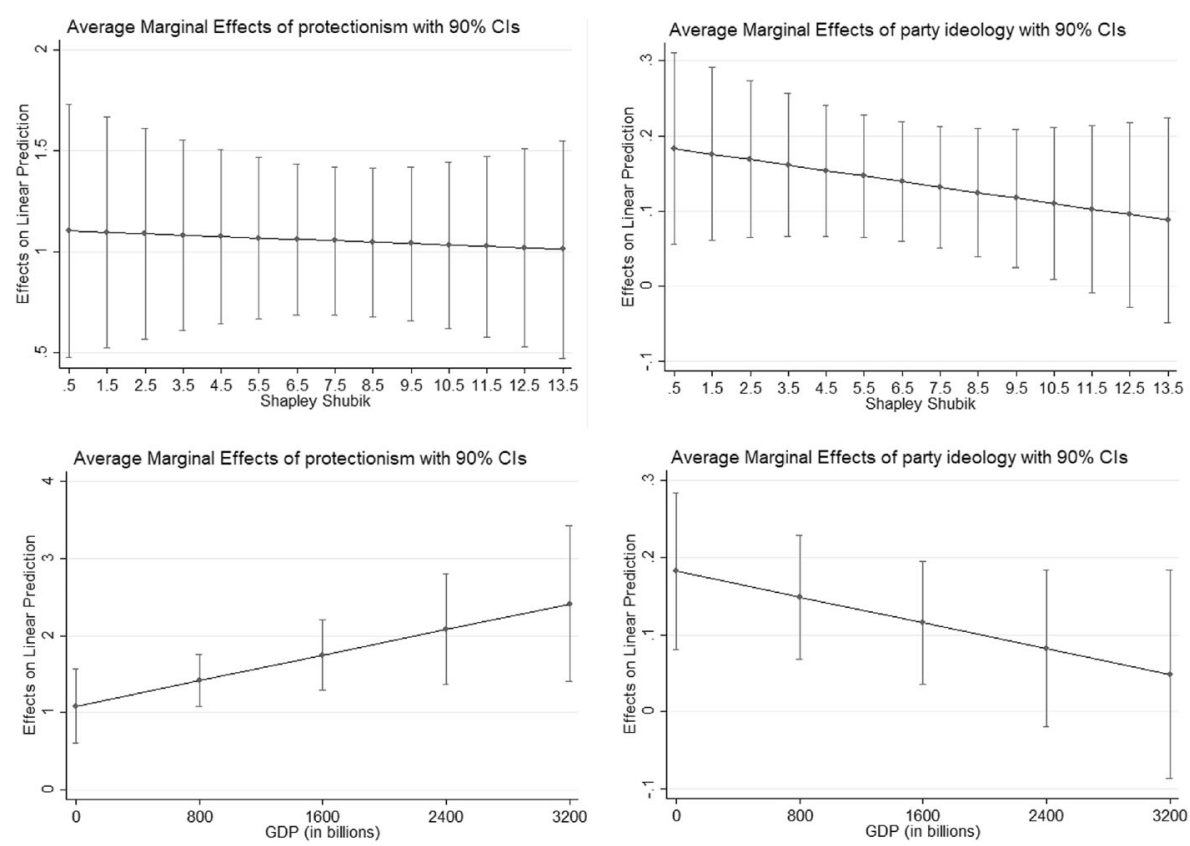

Fig. 2 Marginal effect of level of protectionism and party ideology with voting power (upper panel) and economic power (lower panel)

(3) Once we interact the demand and supply factors of the negotiation process, however, we obtain that economically strong countries realize more DI, if there is a strong demand (in terms of protectionism), whereas the voting power shows no such self-sustaining interaction.

\section{Conclusion}

Liberal intergovernmentalism sees the economy as the one important driving force of integration; economic actors shape integration outcomes, directly influencing national preferences and indirectly EU Council negotiations. We test this general IPE logic in
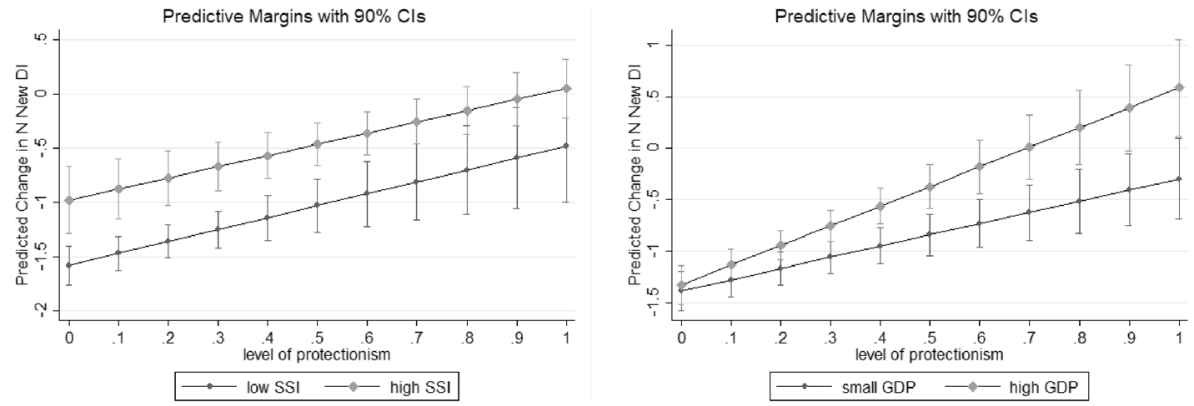

Fig. 3 Predictive margins for the interaction of power and demand; left voting power (SSI), right economic power (GDP) 
our paper for one specific kind of integration and one specific policy field. We analyse differentiated integration in agricultural policy.

We contribute to the study of EU differentiated integration by using a more disaggregated approach than most previous studies (e.g. Duttle 2016; Duttle et al. 2017; Schimmelfennig 2014; Schimmelfennig and Winzen 2017; Winzen 2016; Winzen and Schimmelfennig 2016). The empirical literature has so far attempted to find general explanations for drivers of opt-outs, analyzing the data in highly aggregated ways, including all policy fields over the whole time period since the EU's foundation. The authors mostly used the framework of a comparison of integration theories and concentrated on EU-related country-level attributes as explanatory factors. For primary law, Winzen and Schimmelfennig (2016) find different explanations for DI in treaty revisions and in enlargement rounds. Moreover, there is variation across polices: whereas in treaty revisions DI appears solely in the area of core state powers, enlargement DI appears in common market policies, as well. For secondary law, Duttle (2016) finds negative effects of trade integration and for new members on the level of differentiation, whereas the only consistent positive effect points to member states that deviate from average levels of trade integration. While the latter effect seems plausible and compatible with liberal intergovernmentalism, it is surprising the many other factors should not play a role.

We ascribe this to the fact that a highly aggregated approach cannot account for the great variation in the motives for differentiation in different policy fields, nor for contextual changes over time. Therefore, we suggest a sector specific approach that allows analyzing additional and more specific drivers of DI in EU secondary law. We select DI in the Common Agricultural Policy because this policy field still accounts for the largest share of the EU budget, it is most contested in the Council of Ministers, and we find most differentiations in CAP legal acts.

Building on liberal intergovernmentalism (Moravcsik 1998), we develop a sectorspecific theory that allows to analyze the processes of demanding and supplying differentiation in a two-level approach. We model (1) national preference formation, taking into account agricultural sector and governments interests, (2) EU level decisionmaking via intergovernmental negotiation and voting, and (3) its interactions. To test this theory we employ a time series cross-sectional design.

Our results for the preference formation stage show that more sectoral demand increases thee level of realized differentiations. Furthermore, the governments' receptiveness as measured by party ideology is correlated with DI: conservative governments seem more effective in achieving exemptions. For the negotiation stage at the EU Council of Ministers we find a strong and robust effect of the member states' voting power on realized differentiation. The interaction models show, however, that it is not voting power but economic bargaining strength that moderates the effects of the demand factors. Economically stronger countries realize more DI if they have high levels of agricultural protectionism domestically.

Analyzing secondary law differentiated integration for specific policy fields seems therefore a promising avenue for further research. The selection of fields should take into account their political significance, whether a field can be clearly delineated and has sufficient commonalities, changes over time, but also the relative extent of differentiation. Single regulatory fields (such as environmental policy) might not offer sufficient observations for statistical analysis; aggregating them into regulatory policies could be detrimental to finding common explanatory variables. One promising candidate is core state powers (such as taxation): we would expect high levels of DI to be related to lack of EU support by the 
population and deviating ideological positions of governments. Another area is common market policies, where we conjecture that trade openness, international competitiveness, EU support and conservative governments decrease the extent of DI.

Finally, while the sector-specific approach can deepen our understanding of DI in certain fields, it cannot explain variance across different policy fields or across time. Duttle et al. 2016 give a descriptive account of variation in secondary law across policies and time; Schimmelfennig and Winzen (2017) compare four policy domains in their analysis the Eastern enlargement round. Variation across time has clearly shown to be connected to enlargement (cf. also Schimmelfennig and Winzen 2014, 2017). Sector-specific studies as suggested here might inform analytical approaches to comparing differentiated integration across policies.

Acknowledgements We are grateful for valuable comments from Gerry Alons, Michael Herrmann, Lena Schaffer, the participants of the Workshop "Differentiated Integration after Brexit" at the University of Agder (Kristiansand), November 2017, and three anonymous reviewers of ROIO. We acknowledge the work of Thomas Duttle, Katharina Holzinger, Frank Schimmelfennig, Thomas Winzen and the coding teams in Konstanz and Zürich in collecting and coding the data for EUDIFF2. We thank Marilena Ast for her support with categorizing CAP differentiations.

Funding information Open Access funding provided by Projekt DEAL. Research for this article was funded jointly by the German Research Foundation (HO1811/7-1) and the Swiss National Science Foundation (Project 'Differentiated Integration in Europe').

Open Access This article is licensed under a Creative Commons Attribution 4.0 International License, which permits use, sharing, adaptation, distribution and reproduction in any medium or format, as long as you give appropriate credit to the original author(s) and the source, provide a link to the Creative Commons licence, and indicate if changes were made. The images or other third party material in this article are included in the article's Creative Commons licence, unless indicated otherwise in a credit line to the material. If material is not included in the article's Creative Commons licence and your intended use is not permitted by statutory regulation or exceeds the permitted use, you will need to obtain permission directly from the copyright holder. To view a copy of this licence, visit http://creativecommons.org/licenses/by/4.0/.

\section{References}

Alons, G. (2017). Environmental policy integration in the EU's common agricultural policy: Greening or greenwashing? Journal of European Public Policy, 24(11), 1604-1622.

Anderson, K., \& Valenzuela, E. (2008). Estimates of global distortions to agricultural incentives, 1955 to 2007. World Bank, Washington, DC.

Antonakakis, N., Badinger, H., \& Reuter, W. H. (2016). Efficiency, proportionality and member states' power in the EU Council of ministers. In H. Badinger \& V. Nitsch (Eds.), Routledge international handbooks. Routledge handbook of the economics of European integration (pp. 449-466). London, New York: Routledge.

Armingeon, K., Isler, C., Knöpfel, L., Weisstanner, D., \& Engler, S. (2013). Codebook: Comparative political data set 1960-2013: Bern: Institute of Political Science, University of Berne.

Bailer, S., Mattila, M., \& Schneider, G. (2015). Money makes the EU go round: The objective foundations of conflict in the Council of Ministers. JCMS: Journal of Common Market Studies, 53(3), 437-456.

Banzhaf, J. F. (1965). Weighted voting Doesn't work: A mathematical analysis. Rutgers Law Review, 19, 317343.

Beyers, J., Dür, A., \& Wonka, A. (2018). The political salience of EU policies. Journal of European Public Policy, 25(11), 1726-1737. 
Conceicao-Heldt, E. (2012). The Big Waste? The Common Agricultural Policy: EU Agricultural and Fisheries Policies: an economic and environmental disaster. In H. Zimmermann \& A. Dür (Eds.), The European Union Series. Key Controversies in European Integration (pp. 160-168). Palgrave Macmillan.

Daugbjerg, C. (2003). Policy feedback and paradigm shift in EU agricultural policy: The effects of the MacSharry reform on future reform. Journal of European Public Policy, 10(3), 421-437.

Daugbjerg, C. (2017). Responding to non-linear internationalisation of public policy: The World Trade Organization and reform of the CAP 1992-2013. JCMS: Journal of Common Market Studies, 55(3), 486-501.

Daugbjerg, C., \& Feindt, P. H. (2017). Post-exceptionalism in public policy: Transforming food and agricultural policy. Journal of European Public Policy, 24(11), 1565-1584.

De Búrca, G., \& Scott, J. (2000). Constitutional change in the EU: From uniformity to flexibility? Oxford: Hart Publishing.

Dür, A., \& Mateo, G. (2010). Bargaining power and negotiation tactics: The negotiations on the EU's financial perspective, 2007-13. Journal of Common Market Studies, 48(3), 557-578.

Dutt, P., \& Mitra, D. (2009). Explaining agricultural distortion patterns: The roles of ideology, inequality, lobbying and public finance. Distortions to Agricultural Incentives, Working Paper, 84.

Duttle, T. (2016). Differentiated integration at the EU member state level: An empirical comparison of European integration theories. Baden-Baden: Nomos.

Duttle, T., Holzinger, K., Malang, T., Schäubli, T., Schimmelfennig, F., \& Winzen, T. (2017). Opting out from European Union legislation: The differentiation of secondary law. Journal of European Public Policy, 24(3), 406-428.

Dyson, K., \& Sepos, A. (2010). Differentiation as a design principle and as a tool in the political Management of European Integration. In K. Dyson \& A. Sepos (Eds.), Which Europe? The politics of differentiated integration (pp. 3-23). Basingstoke: Palgrave.

Frey, B. S., \& Eichenberger, R. (1996). Competitive governments for Europe. International Review of Law and Economics, 16(3), 315-327.

Garcia-Duran, P., Casanova, M., \& Eliasson, L. J. (2018). International institutions and domestic policy: Assessing the influence of multilateral pressure on the European Union's agricultural policy. Journal of European Integration, 41(2), 131-146.

Holzinger, K. (2011). EU environmental policy in the joint-decision trap? The critical balance between negative and positive integration. In G. Falkner (Ed.), Exits from the joint-decision trap: Comparing EU policies (pp. 110-127). Oxford: Oxford University Press.

Holzinger, K., \& Schimmelfennig, F. (2012). Differentiated integration in the European Union: Many concepts, sparse theory, few data. Journal of European Public Policy, 19(2), 292-305.

Holzinger, K., \& Tosun, J. (2019). Why differentiated integration is such a common practice in Europe: a rational explanation. Journal of Theoretical Politics, 31(4), 642-659.

Hvidsten, A. H., \& Hovi, J. (2015). Why no twin-track Europe? Unity, discontent, and differentiation in European integration. European Union Politics, 16(1), 3-22.

Jensen, C. B., \& Slapin, J. B. (2012). Institutional hokey-pokey: The politics of multispeed integration in the European Union. Journal of European Public Policy, 19(6), 779-795.

Kim, M.-H. (2010). State preferences and institutional feedback: CAP and European integration. International Political Science Review, 31(3), 323-345.

Kleine, M. (2013). Informal governance in the European Union: How governments make international organizations work. Ithaca, New York: Cornell University Press.

Kleine, M., \& Pollack, M. (2018). Liberal Intergovernmentalism and its critics. Journal of Common Market Studies, 56(7), 1493-1509.

Kölliker, A. (2001). Bringing together or driving apart the union? Towards a theory of differentiated integration. West European Politics, 24(4), 125-151.

Leuffen, D., Malang, T., \& Wörle, S. (2014). Structure, capacity or power? Explaining salience in EU decision-making. Journal of Common Market Studies, 52(3), 616-631.

Leuffen, D., Rittberger, B., \& Schimmelfennig, F. (2013). Differentiated integration: Explaining variation in the European Union. Basingstoke: Palgrave Macmillan.

Magnette, P. (2004). Deliberation or bargaining? Coping with constitutional conflicts in the convention on the future of Europe. In E. O. Eriksen, J. E. Fossum, \& A. J. Menendez (Eds.), Developing a constitution for Europe (pp. 207-225). London: Routledge.

Moravcsik, A. \& Schimmelfennig, F. (2009). Liberal Intergovernmentalism, in: Wiener, A., Boerzel, T.A., Risse, T. (eds): European Integration Theory (3rd ed.), (pp. 64-84). Oxford: Oxford University Press. 
Moravcsik, A. (1998). The choice for Europe: Social purpose and state power from Messina to Maastricht. Ithaca, NY: Cornell Univ. Press.

Moravcsik, A. (2000). De Gaulle between grain and grandeur: The political economy of French EC policy, 1958-1970 (part 1). Journal on Cold War Studies, 2(2), 3-43.

Nugent, N. (2010). The government and politics of the European Union (7th ed.). Basingstoke: Palgrave Macmillan.

Olson, M. (1971). The logic of collective action: Public goods and the theory of groups. Cambridge: Harvard University Press.

Olson, M. (1985). Space, Agriculture, and Organization. American Journal of Agricultural Economics, 67(5), 928.

Redeker, N., \& Walter, S. (2020). We'd rather pay than change - the politics of German non-adjustment in the Eurozone crisis. Review of International Organizations.

Reinhard, J., Holzinger, K., \& Biesenbender, J. (2014). Do arguments matter? Argumentation and negotiation success at the 1997 Amsterdam intergovernmental conference. European Political Science Review, 6(2), 283-307.

Roederer-Rynning, C. (2011). The paradigmatic case: Beyond emergency exits in the common agricultural policy. In G. Falkner (Ed.), Exits from the joint-decision trap: Comparing EU policies (pp. 18-37). Oxford: Oxford University Press.

Schimmelfennig, F. (2014). EU enlargement and differentiated integration: Discrimination or equal treatment? Journal of European Public Policy, 21(5), 681-698.

Schimmelfennig, F. (2018). Brexit: Differentiated disintegration in the European Union. Journal of European Public Policy, 25(8), 1154-1173.

Schimmelfennig, F., \& Winzen, T. (2014). Instrumental and constitutional differentiation in the European Union. JCMS: Journal of Common Market Studies, 52(2), 354-370.

Schimmelfennig, F., \& Winzen, T. (2017). Normalizing differentiated integration: Discriminating and exempting new member states in accession treaties and legislative politics. Journal of European Public Policy, 24(2), 239-258.

Schneider, C. (2009). Conflict, negotiation and European Union enlargement. Cambridge: Cambridge University Press.

Shapley, L. S., \& Shubik, M. (1954). A method for evaluating the distribution of power in a committee system. American Political Science Review, 48(03), 787-792.

Slapin, J. B. (2006). Who is powerful? Examining preferences and testing sources of bargaining strength at European intergovernmental conferences. European Union Politics, 7(1), 51-76.

Slapin, J. B. (2008). Bargaining power at Europe's intergovernmental conferences: Testing institutional and intergovernmental theories. International Organization, 62(1), 131-162.

Steen, A. (1981). The farmers, the consumers and the state: Redistribution and conflicts in Norway. Sweden and the United Kingdom European Journal of Political Research, 9(1), 1-16.

Stubb, A. C. (1996). A categorization of differentiated integration. Journal of Common Market Studies, 34(2), 283-295.

Swinnen, J. F. M. (2009). The growth of agricultural protection in Europe in the 19th and 20th centuries. The World Economy, 32(11), 1499-1537.

Tindemans, L. (1976). 'European Union: Report to the European Council. Bulletin of the European Communities', Supplement 1/1976. Luxembourg (Tindemans Report).

Tracy, M. (1989). Government and agriculture in Western Europe: 1880-1988 (3rd ed.). New York: Harvester-Wheatsheaf.

Tuytschaever, F. (1999). Differentiation in European law. Oxford: Hart Publishing.

Winzen, T. (2016). From capacity to sovereignty: Legislative politics and differentiated integration in the European Union. European Journal of Political Research, 55(1), 100-119.

Winzen, T., \& Schimmelfennig, F. (2016). Explaining differentiation in European Union treaties. European Union Politics, 17(4), 616-637.

Wonka, A., Baumgartner, F. R., Mahoney, C., \& Berkhout, J. (2010). Measuring the size and scope of the EU interest group population. European Union Politics, 11(3), 463-476.

Wooldridge, J. M. (2002). Econometric analysis of cross section and panel data. Cambridge: MIT Press. 


\section{Further Reading}

Garmann, S. (2014). Does globalization influence protectionism? Empirical evidence from agricultural support. Food Policy, 49, 281-293.

Olper, A., Fałkowski, J., \& Swinnen, J. (2014). Political reforms and public policy: Evidence from agricultural and food policies. The World Bank Economic Review, 28(1), 21-47.

Swinnen, J. F. M. (2000). The political economy of public research investment and commodity policies in agriculture: An empirical study. Agricultural Economics, 22(2), 111-122.

Swinnen, J. F. M. (2010). The political economy of agricultural and food policies: Recent contributions, new insights, and areas for further research. Applied Economic Perspectives and Policy, 32(1), 33-58.

Publisher's note Springer Nature remains neutral with regard to jurisdictional claims in published maps and institutional affiliations. 